University of St. Thomas, Minnesota

UST Research Online

Accounting Faculty Publications

Accounting

2011

Ethical Corporate Citizenship: Does it Pay?

Janell Blazovich

University of St. Thomas - Minnesota, blaz7322@stthomas.edu

Kirsten Cook

Texas Tech University

Follow this and additional works at: https://ir.stthomas.edu/ocbacctpub

Part of the Accounting Commons

This Article is brought to you for free and open access by the Accounting at UST Research Online. It has been accepted for inclusion in Accounting Faculty Publications by an authorized administrator of UST Research Online. For more information, please contact asle4660@stthomas.edu. 


\title{
Ethical Corporate Citizenship: Does it Pay?
}

\author{
Janell L. Blazovich \\ Opus College of Business \\ Accounting Department \\ University of St. Thomas \\ St. Paul, MN 55125 \\ Email: jblazovich@stthomas.edu \\ L. Murphy Smith* \\ Department of Accounting \\ Texas A\&M University \\ 4353 TAMU \\ College Station, TX 77843-4353 \\ Tel: 979.845 .3108 \\ Fax: 979.845.0028 \\ Email: Lmsmith@tamu.edu \\ *Corresponding author
}

Authors are listed alphabetically

Acknowledgments: We thank the reviewers, discussant, and participants for their input associated with the paper presentation at the Ethics Conference held at the University of Texas in Austin and the American Accounting Association annual meeting. We also thank the faculty members and Ph.D. students for their input at research workshops held at Texas A\&M University and Mississippi State University. We are particularly grateful for direction provided by Professor Mary Lea McAnally, our friend and colleague. "Don't you realize that in a race everyone runs, but only one person gets the prize? So run to win!” (I Corinthians 9:24). 


\title{
Ethical Corporate Citizenship: Does it Pay?
}

\begin{abstract}
Ethical corporate citizenship and good corporate governance have received increased attention since the financial scandals prevalent at the beginning of the new millennium. This study first explores the relationship of ethical corporate citizenship to financial performance (i.e., greater profitability and efficiency, and lower cost of capital). Second, the study examines whether ethical corporate behavior is associated with a market-value premium. Results of prior studies are mixed. The results of our study contribute directly to the recent accounting literature in which specific aspects of ethical corporate behavior have been explored (Fukami et al. 1997; Ittner and Larker, 1998; Ballou et al., 2003; Clarkson et al., 2004). We use firms listed by Business Ethics as "The 100 Best Corporate Citizens" as our sample of ethical firms. The univariate results of our study indicate a significant relationship between ethical corporate behavior and financial performance (i.e., greater profitability and efficiency, and lower cost of capital). The results of multivariate tests, controlling for prior year market value of equity, yield results which indicate a marginally significant association between being recognized as ethical in that year and market value of equity, but no association between being recognized as ethical at least one time and market value of equity. Nevertheless, given our study's findings of better financial performance and lower risk, we conclude that ethical corporate citizenship does indeed benefit a firm.
\end{abstract}

Key words: Accounting ethics, corporate citizenship, corporate social responsibility. 


\section{Ethical Corporate Citizenship: Does it Pay?}

The importance of ethics and corporate governance in business are widely acknowledged, particularly following the corporate scandals that precipitated passage of the Sarbanes-Oxley Act in 2002. While there have been numerous empirical research studies examining the economic consequences of ethical corporate behavior, the results are mixed (e.g. Griffin and Mahon (1997), Roman et al. (1999), Trebucq and D’Arcimoles (2002), Rushton (2002), Brammer et al. (2005), and Goukasian and Whitney (2007)). Therefore, it is not immediately obvious that we should find a positive association between ethical corporate behavior and corporate financial performance (e.g. profitability). Firms may behave ethically because doing so is inherently the right thing to do, regardless of the financial consequences. Alternately, ethical behavior may increase market value but the association may be delayed by several years. Or firms may behave ethically but be unable to credibly signal their behavior to capital market participants.

This study has two research objectives concerning the relationship of ethical corporate behavior to financial performance and stock market value. First, we assess whether ethical firms have superior financial performance (i.e., greater profitability and efficiency, and lower cost of capital). Second, we investigate whether firms that behave ethically receive a market value premium.

The idea that ethical and socially responsible business practices lead not only to a better world but also to profitability is expressed on the Canadian Business for Social Responsibility (2009) website:

The benefits of CSR (corporate social responsibility) can be quantified and measured.... socially responsible companies experience positive effects on the financial bottom line 
[including] reduced operating costs, increased sales and customer loyalty, increased ability to attract and retain employees, and... increased public image from good works. A recent book, Cause for Success: 10 Companies that Put Profit Second and Came in First (Arena 2004), gives examples of businesses that demonstrate the compatibility of good corporate citizenship and strong financial performance. The critical role of ethics as fundamental to business and accounting is widely acknowledged (cf., Jensen 2009, Keller et al. 2007, Smith 2003).

As a proxy for ethical behavior, we use a publicly available measure, namely, inclusion on the list of "The 100 Best Corporate Citizens" published annually by Business Ethics magazine. Firms on this list are judged superior on a number of internal and external dimensions that collectively indicate ethical corporate behavior. The seven key stakeholders considered by Business Ethics include: customers, employees, local community, minorities (including women), environment, non-U.S. operations, and shareholders. Prior accounting studies have explored the economic consequences of individual firm attributes associated with ethical corporate behavior, such as firm reputation and corporate governance characteristics (Fukami et al. 1997), customer satisfaction ratings (Ittner and Larcker 1998), workplace quality (Ballou et al. 2003), and firm environmental reputation (Clarkson et al. 2004). In contrast, we use a measure that encompasses many dimensions of ethical corporate behavior to investigate whether ethical corporate behavior is associated first with corporate financial performance and second with stock market value.

To address the first research objective, we use univariate tests to evaluate whether ethical behavior is associated with above-average financial performance (i.e., greater profitability and efficiency, and lower cost of capital). To address the second research objective, we use a modified Ohlson (1995) model, adjusted for a scale effect (Lo and Lys 2000), to perform cross- 
sectional tests and thereby determine if firms on the Business Ethics list enjoy a market-value premium.

To evaluate corporate financial performance, we consider profitability, growth, and operational efficiency. We compare list firms to industry benchmarks for a number of accounting performance measures and find that list firms significantly outperform others in their industry. This supports the idea that ethical firms are associated with better profitability, growth, and operational efficiency than the average firm in their industry.

Next, we test the idea that ethical firms are less risky. Rather than rely on a unique risk measure, we use a set of imbricate measures that collectively indicate that ethical firms' future anticipated earnings are less heavily discounted than other firms. In particular, we include balance-sheet measures of liquidity, leverage and composite bankruptcy prediction scores (Altman, 2000); and income statement measures that capture the variability of sales, income and cash flows (Rajgopal and Shevlin, 2002). We find that list firms are less risky than the average firm in their industry.

In addressing the second research objective, we posit that ethical corporate behavior creates a value-relevant intangible asset - in particular, a "structural asset” as described by Lev (2001). This intangible asset derives from the firm's ethical relations with parties both internal and external to the firm. That is, ethical behavior serves to reduce firms' transactions costs. Results of tests using the modified Ohlson (1995) model, adjusted for a scale effect (Lo and Lys 2000), indicate a marginally significant market value premium associated with being recognized on the Business Ethics list that year. Our results indicate no meaningful direct market value premium associated with ethical corporate citizenship in general (i.e., being recognized on the 
list at least one time). Based on our results, ethical corporate citizenship does not appear to create a structural asset.

Taken together, our results indicate that ethical corporate behavior is associated with superior financial performance, but is not associated with a meaningful market value premium per se. That is, ethical behavior appears to allow the ethical firm to realize higher revenues and to incur lower upstream and downstream costs. Our evidence also suggests that ethical firms enjoy a lower cost of debt and equity capital. Yet, a meaningful stock market premium is only associated with being identified as a superior ethical firm that year. However, this in no way takes away from the stock market benefit associated with above-average financial performance and lower risk.

Firms on the Business Ethics list match up to firms on other 'best' and 'worst' lists as follows. Nine of 10 of America's 'most admired companies’ also appeared among the list firms (Fortune Magazine 2005). Five of 10 of 'best employers by minority groups' were found among the list firms (Fortune Magazine 2005b). Three of the 9 companies with 'best benefits' also appeared among the list firms (Fortune Magazine 2005c). Only 7 of the list firms appeared among the 919 financial statement restatements listed by the U.S. General Accounting Office (GAO 2003).

While companies are not obligated to be good corporate citizens, the results of this paper indicate that companies can do the right thing and be financially superior to their industry counterparts. The results of this study should be of interest to both corporate managers and academicians researching ethical corporate citizenship. 
The paper proceeds as follows. The next section summarizes two streams of related prior research. Then we develop our hypotheses, describe our data and methodology, and discuss our results. We conclude in the last section and discuss some potential extensions to our work.

\section{Prior Research}

Two streams of research pertain to our study. The first specifically addresses 'ethical' behavior. The second stream explores individual firm attributes that are associated with ethical corporate behavior. We discuss each of these in turn.

Research that directly addresses the link between ethical behavior and financial performance is mixed. Griffin and Mahon (1997) and Roman et al. (1999) summarize 25 years of prior research on the association between "social performance" and financial performance. Both of these reviews report that prior results are mixed; some studies demonstrate positive associations, others negative associations, and several studies fail to document any association between social and financial performance. Both studies concede that prior results vary because proxies for both social and financial performance differ among the 25 studies.

Research subsequent to these two reviews (i.e., from 1999 onward) also reports mixed results. Goukasian and Whitney (2007) find no significant financial or operational performance benefit associated with ethical and socially responsible corporations. Brammer et al. (2005) find a positive stock performance associated with being identified as an ethical firm. However, Brammer et al. (2005) did not test for the scale effect (or omitted correlated variables), which we do, following an approach recommended by Lo and Lys (2000). Chung et al. (2003) report that "highly ranked firms in reputation" have greater total equity than "lowly ranked firms in reputation.” However Chung et al. (2003) do not control for other factors that influence equity values, such as research and development costs and abnormal earnings. Rushton (2002) finds 
that socially responsible firms (defined using the Dow Jones sustainability group index) outperform other Dow Jones index firms by 36 percent over a three-year period. In contrast, Trebucq and D’Arcimoles (2002) study French firms and conclude that corporate social performance is not related to financial performance. Whereas this prior research has been ad hoc in its empirical methods, we use a theoretical valuation model (Ohlson 1995, 1999) to assess the relationship between ethical corporate behavior and firm value. Moreover, our model controls for other factors that contribute to firm value, including product innovation and brand name.

Waddock and Graves (1997) extend the ‘association’ research described above, by examining the causal direction of the association between financial and social performance. Using a composite measure of corporate social performance (created by the investment firm Kinder, Lydenber, and Domini, or KLD), they regress firms' social performance ratings separately on return on assets, return on equity, and return on sales. They also regress these three metrics on social performance. With the exception of return on equity regressed on corporate social performance, they find all relations are significant at conventional levels. We extend Waddock and Graves (1997) by empirically examining the association between market value of equity and social performance in addition to accounting-based performance metrics.

McWilliams and Siegel (2000) also extend Waddock and Graves (1997), but do so by incorporating research and development into the analysis. When they include research and development in the model they find no relationship between corporate social responsibility and firm performance. Consistent with McWilliams and Siegel (2000) our model controls for research and development costs.

Makni et al. (2008) examine the relationship between corporate social and financial performance in Canadian firms. Similar to our study they use a measure that encompasses 
multiple dimensions of corporate social responsibility. While they find no relationship between their aggregate measure of corporate social responsibility and financial performance, they do identify a negative relationship between the environment dimension and financial performance.

With respect to the second stream of related research, a number of studies consider specific firm attributes or practices associated with ethical conduct and examine whether that specific attribute or practice creates positive economic consequences. Fukami et al. (1997) report that firms with reputations for strong corporate governance and executive compensation policies and practices, generate sustained competitive advantage. Ittner and Larcker (1998) find that customer satisfaction ratings (a measure of firms' posture with respect to an important external constituent) are positively associated with market-value premiums. Ballou et al. (2003) demonstrate a link between workplace quality and firm value. Finally, Clarkson et al. (2004) document a stock-market premium associated with environmental capital expenditure investment by low-polluting firms. In contrast, 'high polluters' do not experience these market premiums. Each of these studies focuses on an individual dimension of ethical behavior. It is possible that firms trade off certain behaviors such that one dimension does not accurately reflect the firms' overall ethical stance. Consequently, we use a broader measure that captures these and other dimensions of ethical conduct and thus, we are able to test whether firms that consistently conduct ethical business with a variety of internal and external firm constituents, enjoy positive economic consequences.

\section{Hypotheses Development}

The link from ethical behavior to financial performance and stock-market value involves corporate reputation and public trust. "One of the most important lessons we can learn from an examination of economic life is that a nation's well being as well as its ability to compete, is 
conditioned by a single, pervasive cultural characteristic: the level of trust inherent in the society” (Fukuyama 1995). Companies that adhere to ethical values engender trust in myriad ways. Customers give repeat business to companies they trust. Supply-chain benefits (including, for example, lower prices and reliable shipping arrangements) result from good relations with vendors and other entities in the supply chain. Banks and other lenders offer lower cost of debt to trustworthy, less risky, firms.

Lyon and Maher (2004) report that auditors assess greater business risk and increase fees for clients that engage in questionable business practices (i.e., bribing top government officials). This provides some empirical support for the converse argument that external auditors may assess a lower risk to clients that engage in ethical business practices, thus requiring fewer tests, which lowers audit fees. Employees who trust their employers are more secure in their job and thus more motivated and likely more productive. Moreover, trusting employees potentially trade off extrinsic compensation and perquisites for the intrinsic benefits that accrue from working for an ethical employer whom they trust.

Green Mountain Coffee Company, a firm on the Business Ethics list, illustrates how positive ethical behavior creates an intangible (structural) asset and improved financial performance. Green Mountain consistently pays coffee producers a premium for quality products and dependable supply arrangements (Asmus 2003). One effect of this over-payment may be increased cost of sales and decreased profit; however, in the long term, this could lead to supplier loyalty, optimum delivery arrangements, and better pricing arrangements. Our research question is whether Green Mountain has better financial performance because of its ethical behavior.

All assets reflect future economic benefits. In assessing future economic benefits, investors assess firms' past performance and gauge future prospects. Firms that engage in ethical 
behavior may experience superior financial performance. Compared to other firms, ethical firms may be able to reduce production and administrative costs (e.g. because of positive external relations with suppliers), or grow revenue and profits more quickly (e.g. because of customer satisfaction and loyalty), or use assets more efficiently (e.g. because of satisfied employees' higher productivity). Collectively, these firm attributes increase profitability, growth, and efficiency. Given the expected positive relationships between ethical behavior and financial performance, the first hypothesis is as follows:

Hypothesis 1: Ethical firms have superior financial performance.

Another possible benefit to firms that operate ethically is that these firms will experience lower risk than other firms. If so, the market will reward reduced risk by discounting future earnings at a lower (less risky) rate, thereby creating a market-value premium. We argue that ethical firms are less risky because they are more trustworthy. Compared to other firms, ethical firms are less likely to face SEC actions for GAAP violations, less likely to announce costly earnings restatements, and less likely to face shareholder, customer, and environmental lawsuits. Moreover, ethical firms have created dependable factors of production such that sales, cash flows and profits are less volatile than for other firms. Froot et al. (1992) show that investors prefer less volatile financial outcomes. Collectively, these factors lower overall firm risk, thereby decreasing the cost of capital. Given the expected relationship between ethical behavior and risk, the second hypothesis is as follows:

Hypothesis 2: Ethical firms are less risky.

While hypothesis 1 and 2 explore the actual financial performance, hypothesis 3 tests the existence of a market value premium. A stock-market premium for an ethical firm may derive from the firm having engendered trust among its constituents and having thereby experienced 
superior financial performance, which market participants anticipate will continue. Ethical behavior may create a value-relevant intangible asset, but GAAP standards do not permit balance-sheet recognition for self-generated intangibles. For example, repeat sales from satisfied customers will be realized (and hence recognized under GAAP) in the future as the sales occur. However, an ethical firm's stock price may reflect the anticipated benefits that accrue from ethical behavior. Amir et al. (2003) conclude that at least some analysts are able to isolate valuerelevant information (about intangible assets) not available in financial reports. This suggests that ethical firm behavior creates an intangible asset (or structural asset) that is potentially not captured by current accounting rules but that is valued by the firm's owners. Thus, our third hypothesis is as follows:

Hypothesis 3: Ethical firms have higher market value of equity.

\section{Data and Methodology}

To test our hypotheses, we use an external measure to identify ethical firms, namely the list of the top 100 ethical firms, published annually by Business Ethics magazine. We acknowledge that this list is not unique, and that other lists are compiled and published annually. Thus, ours are joint tests of the construct validity of the list itself and of the value relevance of ethical corporate behavior.

Each year, the March issue of Business Ethics Magazine identifies “100 Best Corporate Citizens.” These are touted as firms that have outperformed their peers in serving the firms' stakeholders (Asmus 2003). The magazine staff, along with KLD Research and Analytics (a firm specializing in socially responsible investing), considers seven key stakeholders: customers, employees, the community where the firm operates, minorities (including women), the environment, non-U.S. operations, and shareholders via corporate governance measures. An 
ethical score is calculated for each firm and the firms are ranked according to their score. Each year firms are selected for inclusion on the list based on firm practices and data available during the preceding two years. Little of the information used to derive the list is directly available from firms' annual reports - the selection process considers publicly available information (e.g. EPA filings) as well privately collected (survey) data. ${ }^{1}$

Our sample begins with firms on the Business Ethics list for 2000 through 2007. Figure 1 shows list firms and the year(s) they are on the list. We gathered Compustat data for the list firms and all other firms in Compustat for years 1993 to 2008.

\section{FIGURE 1 ABOUT HERE}

To address hypothesis 1 , that ethical firms have superior financial performance, we calculate a number of accounting-based performance measures, including measures of profitability, growth, and efficiency. In particular, our profitability measures are sales divided by total assets, cost of sales margin (cost of sales divided by sales), return on total assets (net income divided by total assets), and return on equity (net income divided by total equity). Our growth measures are year-over-year changes in sales, cost of sales margin and net income. Our efficiency variables include inventory turnover (cost of sales divided by ending inventory), accounts receivable turnover (sales divided by ending accounting receivable), and accounts payable turnover (cost of sales divided by ending accounts payable). We then compare the List firms to their industry benchmark. Using four-digit SIC industry groups to identify industry membership, we define the industry benchmark as the median of each performance measure calculated using all firms in the industry for which Compustat data are available that year. Then, we subtract the industry benchmark from the firm's performance measure. Thus, our medianindustry-adjusted variables measure how much the list firm's performance differs from the 
median value of all other firms within their industry. If the list firms have superior performance, their median-industry-adjusted variables will be significantly different from zero and in the hypothesized direction. For example, we expect ROA (cost of sales margin) will be significantly positive (negative) for list firms. This design is more rigorous than a t-test of means, because it accounts for industry specific changes in performance that controls for performance being a leading indicator of ethics (as Damodaran 2003 suggests).

To address hypothesis 2, that ethical firms are less risky, we evaluate several common accounting-based and market-based risk measures. While it is difficult to accurately measure a firm's riskiness or cost of capital with any one metric (Easton 2003), collectively our risk measures provide a composite picture of firms' overall riskiness. We evaluate balance-sheet measures of liquidity, current ratio and leverage (long-term debt to assets), as well as a credit score measured as follows (Altman 2000):

$$
Z=1.2 X_{1}+1.4 X_{2}+3.3 X_{3}+0.6 X_{4}+X_{5}
$$

where $X_{1}$ is working capital to total assets, $X_{2}$ is retained earnings to total assets, $X_{3}$ is earnings before interest and taxes to total assets, $X_{4}$ is total equity to total debt, and $X_{5}$ is sales to total assets. This Altman Z-score is commonly used to predict bankruptcy and cost of debt issuances (Grice and Ingram 2001) and decreases with the overall risk of the firm.

We also estimate risk metrics that consider the volatility of firms' operations (Froot et al 1992). In particular, we measure the riskiness of income statement and cash flow measures as the standard deviation of the prior eight quarters' sales, operating income, and cash from operations. Because standard deviation is not scale-free, we first scale each performance measure by assets and then calculate the standard deviation of the resulting scaled variables.

Consistent with our performance measures, we calculate median-industry-adjusted risk measures. These variables measure how the list firm's riskiness differs from the riskiness of the 
average firm in their industry. If the list firms are less risky than their industry counterparts, then their median-industry-adjusted measures will be significantly different from zero and in the hypothesized direction. For example, we expect Altman Z-score (standard deviation of net income) will be significantly positive (negative).

Amir et al. (2003) argue that readers cannot always gauge the value of intangible assets solely from the financial statements. As well, signaling ethical behavior is often problematic for business firms. For example, critics complain that corporate codes of conduct are boilerplate and firms touting their corporate codes of conduct are self-serving, while others view such behavior as productive and beneficial to promoting positive ethical behavior. Thus, while investors may value ethical behavior, financial statements and annual reports may not be able to reliably convey a firm's ethical position. This suggests that an external signal of firm ethics, such as inclusion on the Business Ethics list, could provide value-relevant information to the market.

In testing the third hypothesis, we are interested in whether ethical firms have a higher market value of equity. We include in our sample the list firms and all other firms in Compustat for the fifteen-year period, 1994-2008. We use the following modified Ohlson (1995) model as our initial test of hypothesis 3:

$$
\begin{aligned}
M V E_{i, t}= & B V E_{i, t}+E T H I C A L_{\_} E V E R_{i}+E T H I C A L_{\_} I N_{-} Y R_{i, t}+A B_{-} E A R N_{i, t}+R \& D_{i, t}+ \\
& M K T \_S H A R E_{i, t}+\text { Year }_{t}+\text { Industry }_{j}+\varepsilon_{i, t},
\end{aligned}
$$

where $M V E_{i, t}$ is the market value of company i's equity at the end of year $t ; B V E_{i, t}$ is total assets less total liabilities. ${ }^{2} E T H I C A L_{-} E V E R_{i}$ is an indicator variable set equal to ' 1 ' if the firm is on the Business Ethics list in any year from 2000 to 2007 and zero otherwise. ETHICAL_IN_YEAR $R_{i, t}$ is an indicator variable set equal it ' 1 ' if the firm is on the list in that year, zero otherwise. A positive coefficient on $E T H I C A L_{-} E V E R_{i}$ will provide evidence that the market assigns a market premium to ethical firms in general. A positive coefficient on ETHICAL_IN_YEAR $R_{i, t}$ will provide 
evidence that the market assigns a market premium to ethical firms in the year recognized as ethical. $A B \_E A R N_{i, t}$ is abnormal earnings measured as actual earnings for year $t$ less a 10 percent charge for the cost of equity capital. ${ }^{3}$ We also control for other types of intangible assets (apart from the intangible created by ethical behavior) that may increase firm value (Kallapur and Kwan 2004, Hand 2002, Lev 2001, Ghosh 2002). In particular, we include the following variables: $R \& D_{i, t}$, a measure of product innovation (calculated as annual research and development expense scaled by total sales), $M K T_{-} S H A R E_{i, t}$, a proxy for market dominance and brand name (calculated as annual sales scaled by cumulative sales in the firm's four-digit SIC industry group), and Industry $y_{j}$, a proxy for other industry-specific structural assets (a vector of binary indicator variables based on the firm's two-digit SIC code). To control for macroeconomic conditions that affect the market value of equity, we also include Year $_{t}$, year indicator variables (where the latest year in the time-series is omitted).

Since firm size may be impacting our results, we use a scaling approach recommended by Lo and Lys (2000). Consistent with Lo and Lys (2000) we scale all size related variables by lagged MVE and include lagged MVE in the model. The resultant model is as follows:

$$
\begin{aligned}
M V E_{i, t}= & B V E \_L a g M V E_{i, t}+E T H I C A L \_E V E R \_L a g ~ M V E_{i}+ \\
& E T H I C A L \_I N_{-} Y R \_L a g M V E_{i, t}+A B_{-} E A R N_{-} L a g M V E_{i, t}+ \\
& R \& D \_L a g M V E_{i, t}+M K T_{-} S H A R E_{-} L a g M V E_{i, t}+\operatorname{LagMVE}_{i, t}+ \\
& \text { Year }_{t}+\text { Industry }_{j}+\varepsilon_{i, t}
\end{aligned}
$$

\section{Analysis and results}

Sample description

Table 1, Panel A shows the industry membership of our sample firms. Sample firms represent a broad cross-section of firms with the largest proportion in the industrial machinery and financial services industries. 


\section{TABLE 1 ABOUT HERE}

Table 1, Panel B reports descriptive statistics and compares the list and non-list firms over the eight years covered by the Business Ethics list. Recall that to create the list published in March of any given year, KLD compiles information about the firm from the annual report two years prior. Thus, the time lag between KLD analysis and list-publication is between 15 and 21 months. For parity with the KLD methodology, panel B includes data from the annual report from two years prior to the firm's inclusion on the list. List firms are bigger than non-list firms; both mean and median values of list firms' total assets, total sales, and market value of equity are statistically higher than those of non-list firms. On average, significantly fewer list firms have accounting losses: only $7.68 \%$ of list firms report losses compared with $37.01 \%$ of non-list firms. Mean and median market share are higher for list firms compared to non-list firms. Research and development spending as a percentage of sales is higher for non-list firms than list firms.

\section{Tests of Hypothesis 1}

To test Hypothesis 1 that the list firms outperform other firms, we compare the means and medians of the industry-adjusted variables to zero for three important dimensions of performance: profitability, growth, and operational efficiency. Table 2 reports the mean and median of the industry-adjusted performance measures for list firms for 1994 through 2008. We use t-tests (Wilcoxon signed-rank tests) to compare the mean (median) performance measures to zero.

Table 2 shows that list firms are more profitable than the median firm in their industry list firms have higher return on sales, return on assets, and return on equity. The median industry-adjusted measures are all significantly higher than zero (two of the three also have mean industry-adjusted variables higher than zero). Consistent with our speculation that ethical firms 
may enjoy internally generated cost savings, we find that list firms’ cost of sales is significantly lower than the median firm in their industry (median industry-adjusted cost of sales margin equals -0.045 and is statistically less than zero). We find that list firms exhibit stronger growth in operating income (the mean industry-adjusted measure does not differ from zero, but the median industry-adjusted measure is greater than zero). However, we find that list firms experience similar sales and cost of sales margin growth to firms in their industry (median industry-adjusted measures for sales and cost of sales margin growth are not statistically different than zero). Lastly, list firms exhibit more operational efficiency; inventory turnover, accounts receivable turnover, and accounts payable turnover are better than their industry benchmarks.

Taken together, the results presented in Table 2 provide strong evidence in support of Hypothesis 1; ethical firms are financially superior to the average firm in their industry.

\section{TABLE 2 ABOUT HERE}

\section{Tests of Hypothesis 2}

To test Hypothesis 2 that the list firms are less risky, we compare mean and median risk measures of the list firms to the industry benchmarks. These measures are shown in Table 3. First, we consider the balance sheet risk metrics. Compared to their industry benchmarks, list firms have a lower current ratio (median industry-adjusted value is statistically lower than zero). From this we conclude that list firms are less liquid than others in their industry. One potential explanation is that they maintain lower levels of current assets because of their operational efficiencies (documented in Table 2). Additionally, list firms have a higher debt to assets ratio (both mean and median industry-adjusted values are statistically higher than zero). This means list firms are more leveraged on average. These two results are inconsistent with our prediction for Hypothesis 2. Industry benchmark Altman Z-scores, which represent a composite risk 
measure, are significantly greater than zero. Firms with higher Altman Z-scores are predicted to have less likelihood of bankruptcy. This result is consistent with our prediction for Hypothesis 2. Taken together, our balance-sheet risk measures are inconclusive as the evidence is mixed.

\section{TABLE 3 ABOUT HERE}

Second, we compare the volatility of sales, earnings, and cash flows and find that list firms experience less volatility in all three. Comparing list firms to the other firms in their industry, median results are statistically less than zero indicating that list firms have less performance variability than the average firm in their industry. We interpret these results as list firms being less risky, consistent with Froot et al (1992). ${ }^{4}$ Thus, we conclude that list firms exhibit more stable operating results as measured by income statement and cash flow numbers. These results are consistent with our prediction for Hypothesis 2.

While each of the risk measures reported in Table 3 alone would be insufficient to unequivocally conclude that the list firms are less risky, collectively they present evidence that list firms are less risky than the average firm in their respective industries. Taken together our results support our second hypothesis.

\section{Additional tests}

Waddock and Graves (1997) present evidence consistent with social and financial performance being jointly determined. In addition, Damodaran (2003) suggests that financial performance may be a leading indicator of a firm's being perceived as ethical. That is, it could be that firms that perform better financially are perceived as more trustworthy and ethical ex ante, but do not perform better ex post. To shed some light on this issue, we examine financial performance and risk measures after a firm's inclusion on the Business Ethics list. 
Table 4 reports the sample’s median-industry-adjusted measures for our financial performance variables (Panel A) and our risk variables (Panel B) calculated for one and two years after inclusion on the Business Ethics list. Similar to Tables 2 and 3, each variable reported in Table 4 represents the firm-specific difference between the list firm and its industry benchmark, as measured by annual industry median. If the list firms maintain superior performance and reduced risk compared to their industry counterparts, then their medianindustry-adjusted measures will be significantly different from zero in the hypothesized direction. The table confirms that list firms continue to outperform their industry peers in the two years following the match. Taken together, our evidence suggests that ethical firms are less risky and have superior performance in both the short and longer run.

\section{TABLE 4 ABOUT HERE}

\section{Tests of Hypothesis 3}

Table 5 presents regression results for the MVE model. We estimate this model for two periods. First, we include all firms in Compustat for 1994 through 2008. Second, we estimate the model on a sample that includes the list years only, 1998 through 2005. We use these two samples to assess whether the ethical firms consistently have higher market values or whether market values are only higher in the year(s) the firm is on the list.

\section{TABLE 5 ABOUT HERE}

Results are qualitatively the same for both samples so we will discuss just the list years only sample here. Consistent with prior research that uses the Ohlson (1995) model, the coefficient on $B V E$ is strongly positive. As predicted in Hypothesis 3, the coefficients on ETHICAL_EVER and ETHICAL_IN_YEAR are strongly positive, $1,983.770(\mathrm{p}<0.05)$ and $2,480.809(\mathrm{p}<0.05)$ respectively. 
Next, to test for the scale effect (control for omitted correlated variables) we use an approach recommended by Lo and Lys (2000); we scale by lagged MVE. The results will indicate whether being on the ethics list at least one time (in that year) is associated with a change in MVE, as measured by ETHICAL_EVER_LagMVE (ETHICAL_IN_YR_LagMVE). Results of the scaling analysis shown in Table 6 indicate that MVE is not significantly different between firms on the list at least one time and non-list firms (the coefficient on ETHICAL_EVER_Lag_MVE is not statistically different from zero for both the complete timeseries and the list years only analysis). However, the coefficient on ETHICAL_IN_YR_LagMVE is marginally different from zero $(\mathrm{p}<0.10)$ in the predicted direction. This result suggests that firms' ethical behavior in the Business Ethics data compilation year, two years prior to actual recognition on the list, is associated with an increase in firm market value (recall that we evaluate list firms based on historical data; 2005 list year firms are evaluated using 2003 financial data). This result suggests the market recognizes in real-time what the Business Ethics list recognizes in lag. For list years, the market value premium averages about \$15.2 million.

\section{TABLE 6 ABOUT HERE}

The fact that there is no meaningful market premium associated with being on the ethical in general (ETHICAL_EVER_LagMVE) suggests that ethical corporate citizenship does not appear to create an intangible, or structural, asset. However, this should not be taken to mean that there is no economic benefit associated with being ethical. As previously shown, firms on the ethics list do enjoy significantly better financial performance (profitability, growth, and efficiency) and lower risk. The market valuation of the ethical firms incorporates the normal market response associated with better financial performance (profitability, growth, and efficiency) and lower risk. The better financial performance and lower risk associated with 
ethical firms has already benefited them from a stock market valuation standpoint (Nichols and Wahlen 2004). While there have been prior studies that show a market premium (e.g. Brammer et al. 2005, Chung et al. 2003, Ittner and Larcker 1998), this may have been the result of a misspecified model that did not incorporate a scaling analysis (Lo and Lys 2000).

\section{Discussion and Conclusions}

We find that ethical firms have superior financial performance that derives from both internal and external sources: ethical firms have higher profit margins and use their operating assets more efficiently. Together, these allow ethical firms to have higher overall profitability metrics (ROA and ROE). Additionally, we find that firms deemed ethical are perceived as less risky and thus, we conclude that these firms enjoy a lower cost of capital. Our study documents differences in financial and risk metrics for ethical firms both in the year on the list and also one and two years after appearing on the Business Ethics list.

In addition to evaluating financial performance (i.e., profitability, growth, and operating efficiency) and level of risk, this study evaluated whether ethical firms enjoy a stock market premium. We compare firms considered ethical to firms not considered ethical and find, after controlling for prior year's equity, a marginally significant market premium directly associated with ethical behavior, as measured by being on the list of ethical firms that year. We find no market premium associated between being on the list at least once, suggesting that ethical corporate behavior does not create an intangible, or structural, asset. However, this does not mean that firms do not receive any benefit for ethical behavior. These ethical firms have received a better market valuation associated with better financial performance and lower risk.

The results of this study are subject to limitations. First, our proxy for ethical corporate behavior is recognition on a list. While the selection process for the list considers many key 
stakeholders, there could be disagreement about some firms' inclusion on the list. Second, our sample of ethical firms is small, just 742 United States based firms (some firms on the list are not included in the sample due to missing data).

One direct implication of our research is that firms would receive financial performance benefits (i.e., profitability, growth, and operating efficiency) and lower cost of capital by adhering to ethical corporate behavior. Our findings suggest several productive avenues for future research. A study involving long-window excess returns could be productive. If investors over-rely on a firm's inclusion on a list of ethical firms, stock prices of list firms could be bid up too high and subsequently earn negative abnormal returns (see Antunovich and Laster 1999 and Chung et al. 2003 for related evidence). Future research could also explore the specific components of "ethical behavior" such as being environmentally friendly or having superior employee safety programs. 


\section{Endnotes}

${ }^{1}$ Prior to 2003, the selection began with all firms on the Domini Index (a list of socially responsible firms developed by KLD) plus an additional 150 firms that KLD "selected for industry balance and social performance” (Graves et al. 2003). In 2003, the selection began with a broader base of firms: the Russell 1000 and the additional KLD-selected 150 firms.

${ }^{2}$ We use book value of equity because using total assets and total liabilities results in high variance inflation factors.

${ }^{3}$ Abarbanell and Bernard (2000) report consistent results for abnormal earnings calculated with discount rates ranging from nine to 15 percent. Their calculations hold rates constant across time and firms.

${ }^{4}$ Although Froot et al (1992) examines an earlier time period, we make the assumption that during our time period, higher volatility still means higher risk. 


\section{References}

Abarbanell, J. and V. Bernard: 2000, 'Is the U.S. Stock Market Myopic?', Journal of Accounting Research, 38(2): 221-243.

Altman, E. I.: 2000, 'Predicting Financial Distress of Companies: Revisiting the Z-Score and Zeta Models’, Working Paper, New York University.

Amir, E., B. Lev, and T. Sougiannis: 2003, 'Do Financial Analysts Get Intangibles?’, European Accounting Review, 12(4): 635-659

Antunovich, P. and D. Laster: 1999, 'Do Investors Mistake a Good Company for a Good Investment?’, Staff Report No. 60. Federal Reserve Bank of New York (January).

Arena, C.: 2004, Cause for Success: 10 Companies that Put Profit Second and Came in First, (Novato, Canada: New World Library).

Asmus, P.: 2003, '100 Best Corporate Citizens of 2003’, Business Ethics, August. Website: http://www.business-ethics.com/100best.htm (February 2004).

Ballou, B., N. Godwin, and R. Shortridge: 2003, 'Firm Value and Employee Attitudes on Workplace Quality’, Accounting Horizons, 17(3): 329-341.

Brammer, S., C. Brooks, and S. Pavelin: 2005, 'The Stock Performance of America's 100 Best Corporate Citizens', University of Bath Working Paper.

Canadian Business for Social Responsibility: 2009, CSR Research. Canadian Business for Social Responsibility Website: http://www.cbsr.ca/resources/faqs (November, 2009).

Chung, S., K. Eneroth, and T. Schneeweis: 2003, 'Corporate Reputation and Investment Performance: The UK and US Experience’, Working Paper Series. Social Science Research Network Electronic Library.

Clarkson, P, Y. Li, and G. Richardson: 2004, 'The Market Valuation of Environmental Capital Expenditures by Pulp and Paper Companies’, The Accounting Review, April.

Damodaran, A.: 2003, 'In Search of Excellence! Are Good Companies Good Investments?' Working Paper, New York University. Available at Yahoo! Finance, finance.yahoo.com (October 8).

Easton, P. D. and S. J. Monahan: 2003, 'An Evaluation of Accounting Based Measures of Expected Returns’, Working Paper: University of Notre Dame.

Fortune Magazine: 2005, ‘America's Most Admired Companies 2005’, Fortune Magazine. Website: http://www.fortune.com/fortune/mostadmired (June 1). 
Fortune Magazine: 2005b, 'Best Employers by Minority Group’, Fortune Magazine. Website: http://www.fortune.com/fortune/diversity (June 4).

Fortune Magazine: 2005c, ‘Companies with Best Benefits’, Fortune Magazine. Website: http://www.fortune.com/fortune/photoessay/0,18467,1013677-3,00.html (January 24).

Froot, K. A., A.F. Perold and J. C. Stein: 1992, 'Shareholder Trading Practices and Corporate Investment Horizons’, Journal of Applied Corporate Finance, 5(2): 42-58.

Fukami, C., H. Grove and F. Selto: 1997, 'Market Value of Firm Reputation and Executive Compensation Structure’, Working paper, University of Colorado at Boulder.

Fukuyama, F.: 1995, Trust: The Social Virtues and the Creation of Prosperity, (New York, NY: Simon \& Schuster).

GAO: 2003, 'U.S. General Accounting Office, Financial Statement Restatement List’, Website: http://www.gao.gov/new.items/d03395r.pdf (January 17).

Ghosh, A.: 2002, 'The Relevance of Market Share in Corporate Acquisitions', EFMA London Meeting (May).

Goukasian, L. and L. Whitney: 2007, 'Do Ethical and Socially Responsible Firms UnderPerform? Evidence from Financial and Operating Performances’, Pepperdine University Working Paper.

Graves, S. P., S. Woddock, and M. Kelly: 2003, 'How the List is Put Together - The methodology behind the corporate citizenship rankings', Business Ethics, August. Website: http://www.business-ethics.com/100best.htm (February 2004).

Grice, J. S. and R. W. Ingram: 2001, 'Tests of the Generalizability of Altman’s Bankruptcy Prediction Model', Journal of Business Research, 54: 53-61.

Griffin, J. and J. Mahon: 1997, 'The corporate social performance and corporate financial performance debate: Twenty-five years of incomparable research', Business And Society, 36(1): 5-31.

Hand, J.: 2002, 'Intangibles: Management, Measurement, and Reporting', The Accounting Review, 77(3): 696-697.

Ittner, C. and D. Larcker: 1998, 'Are Nonfinancial Measures Leading Indicators of Financial Performance? An Analysis of Customer Satisfaction’, Journal of Accounting Research, 36 (Supplement): 1-35. 
Jensen, Michael C. 2009. 'Integrity: Without it Nothing Works', Harvard Business School NOM Unit Working Paper No. 10-042; Barbados Group Working Paper No. 09-04; Simon School Working Paper No. FR 10-01. Available at SSRN: http://ssrn.com/abstract=1511274.

Kallapur, S. and S. Y. S. Kwan: 2004, 'The Value Relevance and Reliability of Brand Assets Recognized by U.K. Firms’, The Accounting Review. 79 (2): 473-304.

Keller, A.C., K.T. Smith, and L.M. Smith. 2007. 'Do Gender, Educational Level, Religiosity, and Work Experience Affect the Ethical Decision-Making of U.S. Accountants?' Critical Perspectives on Accounting. 18 (3): 299-314. Available at SSRN: http://ssrn.com/abstract=1264036.

Lev, B.: 2001, Intangibles: Management, Measurement and Reporting, (Brookings Institution Press).

Lo, K. and T. Lys: 2000, 'The Ohlson Model: Contribution to Valuation Theory, Limitations, and Empirical Applications’, Journal of Accounting, Auditing \& Finance, 15 (3): 337-371.

Lyon, J., and M. Maher: 2004, 'The Importance of Business Risk in Setting Audit Fees: Evidence from Cases of Client Misconduct', Unpublished working paper, (April).

Makni, R. C., C. Francoeur, and F.Ballavance: 2008, 'Causality between corporate social performance and financial performance: Evidence from Canadian firms’, Journal of Business Ethics, forthcoming (available online).

McWilliams, A. and D. Siegel: 2000, 'Corporate Social Responsibility and Financial Performance: Correlation or Misspecification?’, Strategic Management Journal, 21(5): 603-609.

Nichols, D. C. and J. M. Wahlen: 2004, 'How Do Earnings Numbers Relate to Stock Returns? A Review of Classic Accounting Research with Updated Evidence', Accounting Horizons, 18 (4): 263-286.

Ohlson, J.: 1995, 'Earnings, Equity Book Values, and Dividends in Equity Valuation’, Contemporary Accounting Research, Spring: 661-687.

Ohlson, J.: 1999, 'Earnings, Book Values, and Dividends in a Stewardship Setting with Moral Hazzard’, Contemporary Accounting Research, Fall: 525-540.

Rajgopal, S. and T. Shevlin: 2002, 'Empirical Evidence on the Relation Between Stock Option Compensation and Risk Taking’, Journal of Accounting and Economics, 33 (2): 145-171.

Roman, R., S. Hayibor, and B. Agle: 1999, 'The Relationship Between Social and Financial Performance - Repainting a Portrait’, Business and Society, 39 (1): 109-125.

Rushton, K.: 2002, 'Business Ethics: A Sustainable Approach’, Business Ethics: A European Review, 11: 137-139. 
Smith, L.M. 2003. 'A Fresh Look at Accounting Ethics', Accounting Horizons, 17 (1): 47-49. Available at SSRN: http://ssrn.com/abstract=905142.

Trebucq, S. and C. D’Arcimoles: 2002, ‘The Corporate Social Performance-Financial Performance Link: Evidence from France’, International Accounting Working Paper No. 02-01, University of Bordeaux (March 29).

Waddock, S., and S. Graves: 1997, 'The Corporate Social Performance - Financial Performance Link’, Strategic Management Journal, 18(4): 303-319. 
FIGURE 1

Companies on Business Ethics list of most ethical companies ${ }^{\mathrm{a}}$

\begin{tabular}{|c|c|c|c|c|c|c|c|c|}
\hline Name & 2000 & 2001 & 2002 & 2003 & 2004 & 2005 & 2006 & 2007 \\
\hline 3COM CORP & - & - & - & & & & & \\
\hline $3 \mathrm{M} \mathrm{CO}$ & & - & . & . & . & & . & . \\
\hline ADAPTEC INC. & & & & - & & & & \\
\hline ADOBE SYSTEMS INC & & & - & & & & - & - \\
\hline ADVANCED MICRO DEVICES & & & & & & & . & - \\
\hline ADVENT SOFTWARE INC & & & & & & . & & - \\
\hline AETNA INC & & - & & . & - & & & \\
\hline AFLAC INC & & & & & - & & & \\
\hline AGILENT TECHNOLOGIES INC & & & & & . & & . & - \\
\hline AGL RESOURCES INC & & & & & . & & & \\
\hline AIR PRODUCTS \& CHEM & & & - & - & - & & - & \\
\hline ALASKA AIR GROUP & - & - & & & & & & \\
\hline AMBAC FINANCIAL GP & & & & & & & - & \\
\hline AMERICAN EXPRESS & . & . & - & & & & . & - \\
\hline AMERICAN TOWER CORP & & & & & & . & . & \\
\hline AMGEN INC & & - & - & - & & & & \\
\hline ANALOG DEVICES & & - & - & & & & & \\
\hline APACHE CORP & & & . & & . & & & \\
\hline APOGEE ENTERPRISES & & & & - & & - & - & - \\
\hline APPLE COMPUTER & & - & & & & & - & \\
\hline APPLIED MATERIALS & & - & - & & & - & - & - \\
\hline ARROW ELECTRONIC & & & - & . & & . & & \\
\hline AT\&T CORP & - & - & - & - & - & & & \\
\hline AUTODESK INC & & & - & - & - & - & - & - \\
\hline AVERY DENNISON & - & - & & & & & & - \\
\hline AVON PRODUCTS & - & & & & & - & & - \\
\hline BALDOR ELECTRIC CO & & & & & & & - & - \\
\hline BANK OF AMERICA & & & - & - & & & & \\
\hline BANK OF HAWAII CORP & & & & & & & - & \\
\hline BANK OF NEW YORK & - & & & & & & & \\
\hline BAXTER INTERNATIONAL & - & - & - & & - & - & & - \\
\hline BB\&T CORP & & & & & & & - & - \\
\hline BEA SYSTEMS INC & & & & & & - & & \\
\hline BECTON DICKINSON & & & & - & & & . & \\
\hline BELLSOUTH CORP & & - & & & & & & \\
\hline
\end{tabular}

a The list names 100 companies per year however, due to missing data not all companies are used in this paper's analysis. Only list firms used in subsequent analysis are included in this figure. 
FIGURE 1 (continued)

Companies on Business Ethics list of most ethical companies

\begin{tabular}{|c|c|c|c|c|c|c|c|c|}
\hline Name & 2000 & 2001 & 2002 & 2003 & 2004 & 2005 & 2006 & 2007 \\
\hline BEST BUY CO INC & & & & & & & & . \\
\hline BIOMET INC & . & . & & & & & - & \\
\hline BRADY CORP & - & - & - & - & - & - & - & . \\
\hline BRIGHT HORIZONS FAMILY & & & & & - & - & - &. \\
\hline BRISTON-MYERS SQUIBB & & & & & & & & . \\
\hline CA INC & & . & & . & & & & \\
\hline CAMPBELL SOUP CO & - & & & & & & & \\
\hline CASCADE NATURAL GAS & & & & & - & & & \\
\hline CATHAY GENERAL BANCORP & & & & & & & - & - \\
\hline CELERA CORP & & & & & & & & . \\
\hline CHAMPION ENTERPRISES & & & & . & & . & & \\
\hline CHURCH \& DWIGHT & - & & & & . & & & \\
\hline CIGNA CORP & & - & - & & & & & \\
\hline CIMAREX ENERGY & & & & & . & & & \\
\hline CINCINNATI FINANCIAL & & & & & & - & & . \\
\hline CISCO SYSTEMS & - & - & - & - & - & - & - & . \\
\hline CITIGROUP INC & & & & & & & - & \\
\hline CLOROX & - & - & . & . & . & & & \\
\hline CME GROUP INC & & & & & & & . & - \\
\hline COCA-COLA CO & - & & & & & & & \\
\hline COGNIZANT TECH SOLUTIONS & & & & & & & & . \\
\hline COHERENT INC & & & & & & - & - & 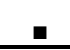 \\
\hline COLDWATER CREEK INC & & & & & & & & . \\
\hline COLGATE-PALMOLIVE & & & & & & & & - \\
\hline COMERICA INC & & & & & - & & & \\
\hline CONSTELLATION ENERGY & - & & & & & & & \\
\hline CORNING INC & & - & . & & & & & \\
\hline CROWN CASTLE INTL & & & & & & 모 & & \\
\hline CROWN HOLDINGS & - & - & & & & & & \\
\hline CUMMINS INC & - & - & - & - & - & - & - &. \\
\hline CVS CORP & - & & & & & & & \\
\hline CYPRESS SEMICONDUCTOR & & & & & & 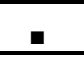 & & \\
\hline D R HORTON & & & & & & - & & \\
\hline DARDEN RESTAURANTS & & & & & & & - & \\
\hline DEERE \& CO & - & - & - & - & - & - & & - \\
\hline DELL INC & - & - & & - & - & - & - &. \\
\hline DELPHI CORP & & & - & - & - & & & \\
\hline DELUXE CORP & & & & . & - & & & \\
\hline
\end{tabular}


FIGURE 1 (continued)

Companies on Business Ethics list of most ethical companies

\begin{tabular}{|c|c|c|c|c|c|c|c|c|}
\hline Name & 2000 & 2001 & 2002 & 2003 & 2004 & 2005 & 2006 & 2007 \\
\hline DEVRY INC & - & - & - & & & & & \\
\hline DIME BANCORP & - & - & & & & & & \\
\hline DIONEX CORP & - & & & & - & & & \\
\hline DISNEY (WALT) & - & - & & & & & & \\
\hline DORAL FINANCIAL & & & & & - & - & & \\
\hline DOW JONES & & - & & - & . & & & \\
\hline EAST WEST BANCORP & & & & & & & - & \\
\hline EASTMAN CHEMICAL & & & & - & & & & \\
\hline EASTMAN KODAK CO & & - & - & - & - & & - & - \\
\hline ECOLAB INC & - & - & - & - & - & - & - & - \\
\hline EDWARDS (A G) & 모 & & & & & & & \\
\hline ELECTRONIC ARTS INC & & & & & - & - & & \\
\hline EMC CORP & - & - & & & & & & \\
\hline EMERSON ELECTRIC & & & - & & - & & & \\
\hline ENDO PHARMACEUTICALS & & & & & & - & & \\
\hline ENERGEN CORP & $\square$ & & - & & - & & & \\
\hline ENERGY CONVERSION & & & & & & & & - \\
\hline EXPEDIA INC & & & & - & & & & \\
\hline FANNIE MAE & - & - & - & - & - & & & \\
\hline FEDRL HOME LOAN MTGE & & - & - & & & & - & $\square$ \\
\hline FEDEX & & & - & 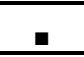 & - & . & & \\
\hline FIFTH THIRD BANK & - & - & & & & & & \\
\hline FIRST HORIZON NATIONAL & & & & - & - & - & - & 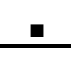 \\
\hline FIRSTFED FINANCIAL & - & & - & - & - & - & & \\
\hline FLEETBOSTON FINANCIAL & & & & - & & & & \\
\hline FOUNDRY NETWORKS & & & & & & - & & \\
\hline FULLER (H. B.) & & - & - & - & & & & \\
\hline GAIAM INC & & & & & & - & - & - \\
\hline GAP INC & 므. & . & & & & & . & 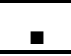 \\
\hline GEN-PROBE INC & & & & & & & & 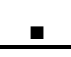 \\
\hline GENENTECH & & & & & & - & - & \\
\hline GENERAL MILLS & - & & - & . & & - & - & $\square$ \\
\hline GOLDEN WEST FINANCIAL & - & - & . & . & . & & & \\
\hline GOOGLE INC & & & & & & & & - \\
\hline GRACO INC & - & - & - & - & - & - & - & \\
\hline GRAINER (W W) INC & & & & & & & - & 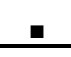 \\
\hline GRANITE CONSTRUCTION & $\square$ & & & & & & & \\
\hline GREAT ATL \& PAC TEA & & & & - & & & & \\
\hline GREEN MOUNTAIN COFFEE & & & & - & - & - & . & - \\
\hline
\end{tabular}


FIGURE 1 (continued)

Companies on Business Ethics list of most ethical companies

\begin{tabular}{|c|c|c|c|c|c|c|c|c|}
\hline Name & 2000 & 2001 & 2002 & 2003 & 2004 & 2005 & 2006 & 2007 \\
\hline GUIDANT CORP & - & - & - & . & & - & & \\
\hline HANSEN NATURAL CORP & & & & & & & & - \\
\hline HARMAN INTERNATIONAL & & - & - & . & . & - & & \\
\hline HARTFORD FINANCIAL & & & & . & . & & . & \\
\hline HASBRO INC & & & & - & & & & \\
\hline HEARTLAND FINANCIAL & & & & & & & - & - \\
\hline HEINZ (H J) CO & & & & & & & & - \\
\hline HEWLETT-PACKARD & - & - & - & - & - & - & - & \\
\hline HNI CORP & & & & & - & & & \\
\hline HOME DEPOT INC & - & - & - & & & & & \\
\hline HONEYWELL INTL & & - & & & & & & \\
\hline IDEXX LABS INC & & & & & & & . & \\
\hline IKON OFFICE SOLUTIONS & & & & - & & & & \\
\hline IMATION CORP & & & & - & - & & & \\
\hline INTEL CORP & - & - & - & - & - & - & - & 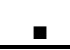 \\
\hline INTERFACE INC & & & & & & $\square$ & - & - \\
\hline IBM & - & - & - & - & - & & - &. \\
\hline ITRON INC & & & & & & & & . \\
\hline ITT CORP & & & & - & & & & \\
\hline JOHNSON \& JOHNSON & & & & & & & - & 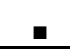 \\
\hline JOHNSON CONTROLS INC & & & & & & & . & \\
\hline JONES LANG LASALLE & & & & & & & &. \\
\hline JP MORGAN CHASE & - & - & - & & & & & \\
\hline JUNIPER NETWORKS & & & & & & - & & \\
\hline KELLOGG & & & & & - & & - &. \\
\hline KEYCORP & & & & & & & - &. \\
\hline KIMBERLY-CLARK GROUP & & & & & & & &. \\
\hline KINDER MORGAN & & & & - & & & & \\
\hline KNIGHT-RIDDER & - & & & & & & & \\
\hline KROGER CO & & - & - & & & & & \\
\hline LAM RESEARCH & & & & & & - & - & - \\
\hline LENNAR CORP & & & & & & - & & \\
\hline LEXMARK INTL & & & - & - & - & & &. \\
\hline LILLIAN VERNON & & - & & & & & & \\
\hline LILLY (ELI) \& CO & - & - & - & & & & & \\
\hline LINCOLN NATIONAL & - & - & & & & & & \\
\hline LSI CORP & & - & & & & & & \\
\hline LUCENT TECHNOLOGIES & - & & - & & & & & \\
\hline MARRIOTT INTL & & & . & & & . & & \\
\hline
\end{tabular}


FIGURE 1 (continued)

Companies on Business Ethics list of most ethical companies

\begin{tabular}{|c|c|c|c|c|c|c|c|c|}
\hline Name & 2000 & 2001 & 2002 & 2003 & 2004 & 2005 & 2006 & 2007 \\
\hline MATTEL INC & & & & & & & & . \\
\hline MBIA INC & & & . & - & & & & \\
\hline MBNA CORP & - & - & - & & & & & \\
\hline MCDONALDS CORP & & - & - & & & & & \\
\hline MCGRAW-HILL COMPANIES & & & & & & & - & . \\
\hline MEDTRONIC INC & - & - & - & - & - & & & \\
\hline MENS WEARHOUSE INC & & & & & & - & & \\
\hline MERCK \& CO & - & - & - & - & - & & & \\
\hline MERCURY GENERAL CORP & & & & & & - & & \\
\hline MERIX CORP & & & - & & & - & & \\
\hline MGE ENERGY INC & & & & - & . & - & & \\
\hline MICRON TECHNOLOGY & & & & & & & - & \\
\hline MICROSOFT CORP & . & & . & . & & & & . \\
\hline MILLER (HERMAN) & - & - & - & - & - & - & - & - \\
\hline MILLIPORE CORP & & & & & & - & & \\
\hline MINERALS TECHNOLOGIES & & & & - & - & & & \\
\hline MODINE MFG CO & . & - & . & - & . & . & - & \\
\hline MOLINA HEALTHCARE & & & & & & & - & \\
\hline MOLSON COORS BREWING & - & - & - & - & - & & & \\
\hline MOTOROLA INC & - & - & - & - & . & & . & . \\
\hline NATIONAL CITY & & & & . & & & & \\
\hline NATIONWIDE FINL SVCS & & & & & & & - & \\
\hline NATURES SUNSHINE PROD & & & & - & - & - & - & \\
\hline NETAPP INC & & & - & & & & & 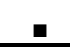 \\
\hline NEW YORK TIMES CO & - & - & - & - & . & - & & \\
\hline NIKE & & & & & & . & . & - \\
\hline NORDSON CORP & & - & - & - & - & - & & \\
\hline NORDSTROM INC & - & - & & & & & - &. \\
\hline NORTHERN TRUST & & - & - & - & & - & - & \\
\hline NORTHWEST NATURAL GAS & & - & - & - & - & - & - &. \\
\hline NOVELL INC & & - & & & & - & & \\
\hline NUCOR CORP & & . & - & & & & &. \\
\hline NUTRISYSTEM INC & & & & & & & & - \\
\hline NUVEEN INVESTMENTS & & & & - & . & - & & \\
\hline NVIDIA CORP & & & & - & & & & \\
\hline OFFICE DEPOT INC & & & & & & & . &. \\
\hline ONEOK INC & - & - & - & & & & & \\
\hline ORACLE CORP & & - & - & & & & & \\
\hline ORMAT TECHNOLOGY & & & & & & & &. \\
\hline
\end{tabular}


FIGURE 1 (continued)

Companies on Business Ethics list of most ethical companies

\begin{tabular}{|c|c|c|c|c|c|c|c|c|}
\hline Name & 2000 & 2001 & 2002 & 2003 & 2004 & 2005 & 2006 & 2007 \\
\hline OXFORD HEALTH PLANS & & & - & & & & & \\
\hline PEP BOYS & & & & . & & & & \\
\hline PEPSI BOTTLING GROUP & & & & & - & & & \\
\hline PEPSICO INC & & & & & & & . & . \\
\hline PITNEY BOWES INC & 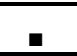 & . & 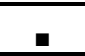 & 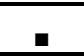 & . & . & . &. \\
\hline PIXAR & & & & & - & $\square$ & & \\
\hline PLANTRONICS INC & & & & & & - & & \\
\hline PNC FINANCIAL & . & & - & & & & & \\
\hline PPG INDUSTRIES & & & - & & & & & \\
\hline PRINCIPAL FINANCIAL GRP & & & & & & & - & - \\
\hline PROCTER \& GAMBLE & - & - & - & - & - & $\square$ & $\square$ & \\
\hline PROGRESSIVE CORP & - & & & & & & & \\
\hline PRUDENTIAL FINANCIAL & & & & & & 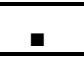 & & \\
\hline QRS CORP & & . & & & & & & \\
\hline QUALCOMM INC & & & - & & & & & \\
\hline RAMBUS INC & & & & & & $\square$ & & \\
\hline RESOLUTE ENERGY & & & & - & - & - & & \\
\hline ROCKWELL COLLINS & & & & & & & $\square$ & - \\
\hline ROHM AND HAAS & & & & & . & - & & \\
\hline SALESFORCE.COM INC & & & & & & & - &. \\
\hline SAPIENT CORP & & & & & & . & & \\
\hline SARA LEE CORP & & - & & & - & & & \\
\hline SCHOLASTIC CORP & & - & 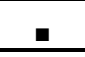 & - & . & - & & \\
\hline SCHWAB (CHARLES) & - & - & - & & & & & \\
\hline SIERRA HEALTH SERVICES & & & & & & & & - \\
\hline SIRIUS XM RADIO & & & & & & $\square$ & & \\
\hline SLM CORP & - & - & & & - & - & - &. \\
\hline SMUCKER (JM) CO & & & & - & - & - & & \\
\hline SOLECTRON CORP & . & . & . & & & & & \\
\hline SONOCO PRODUCTS & - & - & - & - & - & & & \\
\hline SOUTHWEST AIRLINES & . & . & - & - & - & - & - &. \\
\hline SPARTAN MOTORS & & & & . & - & & & \\
\hline SPX CORP & - & & & & & & & \\
\hline STAPLES INC & & & & - & - & - & & \\
\hline STARBUCKS CORP & - & - & - & - & - & - & - &. \\
\hline STATE STREET CORP & - & - & - & - & & & - &. \\
\hline STEELCASE INC & & & & & & & & - \\
\hline STUDENT LOAN CORP & & & & & & & - & \\
\hline SUN MICROSYSTEMS & 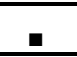 & . & - & . & & & . & 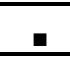 \\
\hline
\end{tabular}


FIGURE 1 (continued)

Companies on Business Ethics list of most ethical companies

\begin{tabular}{|c|c|c|c|c|c|c|c|c|}
\hline Name & 2000 & 2001 & 2002 & 2003 & 2004 & 2005 & 2006 & 2007 \\
\hline SUPERVALU INC & & & & . & & & & \\
\hline SYMANTEC CORP & & & - & - & - & - & - & \\
\hline SYNOVIS LIFE TECH & & & & & & - & & \\
\hline SYNOVUS FINANCIAL & & & & & & & - & \\
\hline TARGET CORP & - & - & & & & & & \\
\hline TD BANKNORTH & & & & & & - & & \\
\hline TECHNE CORP & & & & & & & & - \\
\hline TELLABS INC & - & - & - & & & - & & \\
\hline TENNANT C & - & - & - & & & & - & \\
\hline TEXAS INSTRUMENTS & - & - & - & & - & - & . & - \\
\hline THERMO FISHER SCIENTIFIC & & & & . & . & & & \\
\hline TIMBERLAND & - & - & - & - & - & - & - & 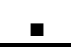 \\
\hline TIME WARNER INC & - & - & & & & & & \\
\hline TIMKEN CO & & & & & - & & - & \\
\hline TJX COMPANIES & - & & & & & & & \\
\hline TOOTSIE ROLL & $\square$ & & & & & $\square$ & & \\
\hline TOTAL SYSTEM SERVICES & & & & & & - & - & \\
\hline TRADESTATION GROUP & & & & & & & & - \\
\hline TRAVELERS COS INC & - & - & - & & - & - & - & $\square$ \\
\hline TREX CO INC & & & & & - & & & - \\
\hline TRIBUNE CO & & - & - & & - & & & \\
\hline UNIONBANCAL CORP & & & & & - & - & - & \\
\hline UNITED NATURAL FOODS INC & & & & & & & - & \\
\hline UNITED PARCEL SERVICE & & & & & & & - & - \\
\hline UNUM GROUP & - & & - & & & & & \\
\hline VALASSIS COMMUNICATIONS & & & & & & - & & \\
\hline VIASYS HEALTHCARE & & & & - & & & & \\
\hline WACHOVIA & - & & & & - & & & \\
\hline WAINWRIGHT BANK \& TRUST & & & & & & & . & 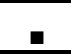 \\
\hline WAL-MART STORES & - & & & & & & & \\
\hline WASHINGTON POST & - & & & & & & - & \\
\hline WASTE MANAGEMENT & & & & & - & - & & \\
\hline WEIGHT WATCHERS & & & & & - & & & \\
\hline WELLS FARGO & & & - & & & - & - & 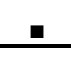 \\
\hline WENDY'S & & & - & & - & & & \\
\hline WGL HOLDINGS INC & & & & - & - & - & - & - \\
\hline
\end{tabular}


FIGURE 1 (continued)

Companies on Business Ethics list of most ethical companies

\begin{tabular}{|c|c|c|c|c|c|c|c|c|}
\hline Name & 2000 & 2001 & 2002 & 2003 & 2004 & 2005 & 2006 & 2007 \\
\hline WHIRLPOOL & - & - & - & - & - & - & - & \\
\hline WHOLE FOODS MARKETS & . & - & & - & - & & - & - \\
\hline WILD OATS MARKETS & & & & - & 무 & & - & - \\
\hline WORTHINGTON INDUSTRIES & & & & - & - & & & \\
\hline WRIGLEY (WM) JR CO & & & & & & & & - \\
\hline XEROX & - & & & & & - & & - \\
\hline XILINX & & - & - & & & - & - & - \\
\hline XM SATELLITE RADIO & & & & & & a & & \\
\hline XTO ENERGY INC & & & & & - & & & \\
\hline ZIMMER HOLDINGS & & & & & - & - & - & \\
\hline
\end{tabular}


TABLE 1

Demographics and descriptive statistics of financial variables for firms on the Business Ethics list each year from 2000 to 2007

Panel A: Industry representation for firms on the list in years 2000 and $2007^{\mathrm{a}}$

\begin{tabular}{lccc} 
Industry Description & $\begin{array}{c}\text { Two-digit } \\
\text { SIC }\end{array}$ & $\begin{array}{c}\text { Percentage } \\
\text { of sample in } \\
\text { year 2000 }\end{array}$ & $\begin{array}{c}\text { Percentage } \\
\text { of sample in } \\
\text { year 2007 }\end{array}$ \\
\hline Food and kindred products & 20 & $5.81 \%$ & $7.29 \%$ \\
Furniture and fixtures & 25 & $1.16 \%$ & $2.08 \%$ \\
Paper and allied products & 26 & $2.33 \%$ & $3.13 \%$ \\
Printing, publishing, and allied industries & 27 & $3.49 \%$ & $1.04 \%$ \\
Chemicals and allied products & 28 & $8.14 \%$ & $7.29 \%$ \\
Industrial and commercial machinery & 35 & $13.95 \%$ & $11.46 \%$ \\
Electronic equipment and components & 36 & $8.14 \%$ & $8.33 \%$ \\
Instruments and related products & 38 & $4.65 \%$ & $4.17 \%$ \\
Miscellaneous manufacturing industries & 39 & $1.16 \%$ & $2.08 \%$ \\
Transportation by air & 45 & $2.33 \%$ & $1.04 \%$ \\
Electric, gas and sanitary services & 49 & $3.49 \%$ & $3.13 \%$ \\
Food stores & 54 & $1.16 \%$ & $2.08 \%$ \\
Apparel and miscellaneous retail & $56 \& 59$ & $4.65 \%$ & $6.26 \%$ \\
Depository institutions & 60 & $11.63 \%$ & $8.33 \%$ \\
Other non-depository financial services & $61-63$ & $10.47 \%$ & $9.38 \%$ \\
Business services & 73 & $3.49 \%$ & $8.33 \%$ \\
Other & various & $13.95 \%$ & $14.58 \%$
\end{tabular}

a The list names 100 companies per year however, due to missing data not all companies are used in this paper's analysis. Only list firms used in subsequent analysis are used to tabulate this table. 
TABLE 1 (continued)

Panel B: Means and medians for the list firm-years, 1998-2005 and all non-list firms in Compustat, 1998-2005

\begin{tabular}{|c|c|c|c|c|c|c|}
\hline & \multicolumn{3}{|c|}{ List firm years (1998 to 2005$)^{b}$} & \multicolumn{3}{|c|}{ All other firms in Compustat (1998 to 2005) } \\
\hline & $\mathbf{N}$ & Mean & Median & $\mathbf{N}$ & Mean & Median \\
\hline Total assets & 742 & $3,494.77 *$ & $5,353.49 *$ & 59,502 & 971.47 & 180.71 \\
\hline Return on assets & 742 & $6.99 \% *$ & $6.15 \% *$ & 59,502 & $-10.39 \%$ & $1.26 \%$ \\
\hline Percent of firms with loss & 742 & $7.68 \% *$ & N.A. & 59,502 & $37.01 \%$ & N.A. \\
\hline Total sales & 742 & $10,42.49 *$ & $3,991.54 *$ & 59,502 & 560.55 & 91.08 \\
\hline Book value of equity & 742 & $5,445.54 *$ & $1,929.53 *$ & 59,502 & 333.12 & 69.70 \\
\hline Market value of equity & 742 & $27,108.03^{*}$ & $7,987.69 *$ & 59,502 & 678.29 & 121.23 \\
\hline R\&D spending to sales & 411 & $9.06 \% *$ & $5.41 \% *$ & 22,146 & $42.71 \%$ & $10.28 \%$ \\
\hline Market share & 742 & $18.64 \% *$ & $9.22 \% *$ & 59,502 & $3.90 \%$ & $0.26 \%$ \\
\hline
\end{tabular}

\footnotetext{
Notes to Table 1:

${ }^{a}$ Since the list year corresponds to financial data two years prior, data provided for the list years 2000-2007 are 1998-2005.

${ }^{\mathrm{b}}$ The table reports the means, and medians separately for 742 list firm-years (100 firms on list for each of eight years with some firm-year observations leaving the sample due to missing data) and all other firms in Compustat. For consistency, firms not included in regression models, due to missing data, are not included on this table.

${ }^{\text {c } F i r m s ~ a p p e a r i n g ~ o n ~ t h e ~ l i s t ~ a r e ~ n o t ~ i n c l u d e d ~ i n ~ t h e ~ " A l l ~ o t h e r ~ f i r m s " ~ c o l u m n s ~ f o r ~ l i s t ~ o r ~ n o n-l i s t ~ y e a r s . ~ A l l ~ c o n t i n u o u s ~ v a r i a b l e s ~ f o r ~ f i r m s ~ n o t ~ o n ~ t h e ~ l i s t ~ h a v e ~}$ been winsorized at the $5^{\text {th }}$ and $95^{\text {th }}$ percentile. List firm years have not been winsorized.
}

All data are retrieved from Compustat to compute the following variables:

Total assets $=$ DATA6 (AT) in millions of dollars.

Return on assets $=$ Net income $($ DATA172, NI) $/$ Total assets $($ DATA6, AT), in percent.

Percent of firms with loss $=1$ if Net income (DATA172, NI) is negative; zero otherwise.

Total sales $=$ DATA12 (SALE), in millions of dollars.

Book value of equity $=$ Total assets $($ DATA6, AT) - Total liabilities (DATA181, LT), in millions of dollars.

Market value of equity $=$ Price per share $($ DATA199, PRCC_F $) \times$ Shares outstanding (DATA25, CSHO), in millions of dollars.

R\&D spending to sales $=$ R\&D expense $($ DATA46, XRD) $/$ Total sales (DATA12, SALE), in percent.

Market share $=$ Total sales (DATA12, SALE) $/ \sum$ Total sales (DATA12, SALE) for all firms in four-digit SIC code, in millions of dollars .

* Mean (or median) for list firms is significantly different than mean for non-list firms at $\mathrm{p}=0.05$ or better using a one-tailed student t-test (Wilcoxon-MannWhitney test). 
TABLE 2

List firms compared to industry benchmarks

for financial performance measures, 1994-2008

Profitability variables

Sales to total assets

Cost of sales margin

List firms

unadjusted variables

List firms

median industry-adjusted variables

Return on assets

Return on equity

\begin{tabular}{crrrrr}
\hline $\mathbf{N}$ & Mean & Median & $\mathbf{N}$ & Mean & Median \\
& & & & & \\
2,362 & 1.165 & 1.026 & 2,362 & $0.114^{*}$ & $0.041^{*}$ \\
3,004 & 0.645 & 0.550 & 3,004 & 0.013 & $-0.045^{*}$ \\
3,004 & 0.053 & 0.054 & 3,004 & $0.088^{*}$ & $0.025^{*}$ \\
3,001 & 0.580 & 0.175 & 3,001 & 0.504 & $0.068^{*}$ \\
& & & & & \\
& & & & & \\
2,816 & 0.203 & 0.095 & 2,816 & $0.092^{*}$ & 0.000 \\
2,816 & 0.005 & -0.003 & 2,816 & $0.008^{*}$ & 0.000 \\
2,875 & -9.283 & 0.121 & 2,875 & -9.173 & $0.050^{*}$ \\
& & & & & \\
2,539 & 33.488 & 5.782 & 2,539 & $23.470^{*}$ & $0.216^{*}$ \\
2,956 & 12.451 & 6.153 & 2,956 & $2.373^{*}$ & $0.047^{*}$ \\
2,906 & 9.707 & 7.210 & 2,906 & $2.312^{*}$ & $0.005^{*}$ \\
\hline
\end{tabular}

Growth variables

Sales growth

Cost of sales margin growth

Net income growth

2,816

2,816

$0.008^{*}$

0.000

Net income growth

Efficiency variables

Inventory turnover

Acc. receivable turnover

$2,956 \quad 12.451$

7.210

2,906

$2.373^{*}$

$0.005^{*}$

Notes to Table 2:

The table reports means and medians for the period 1994-2008 for the 742 list firms (100 firms on the Business Ethics list for each of eight years with some list firms leaving the sample due to missing data).

All data are retrieved from Compustat to compute the following variables:

Sales to total assets $=$ Sales (DATA12, SALE) $/$ Total assets (DATA6, TA), not calculated for banks.

Cost of sales margin $=$ Cost of sales (DATA41, COGS) $/$ Sales (DATA12, SALE), not calculated for banks.

Return on assets $=$ Net income $($ DATA172, NI) $/$ Total assets (DATA6, TA).

Return on equity $=$ Net income (172, NI) $/$ Common equity (DATA11, CEQT).

Sales growth $=\left(\right.$ Sales $_{t}-$ Sales $\left._{t-1}\right) /$ Sales $_{t-1}$.

Cost of sales margin growth $=\left(\right.$ Cost of sales margin $_{t}-$ Cost of sales margin $\left._{t-1}\right) /$ Cost of sales margin $t-1$.

Net income growth $=\left(\right.$ Net income $_{t}-$ Net income $\left._{t-1}\right) /$ Net income $_{t-1}$, where Net income $=$ DATA172 $(\mathrm{NI})$ in millions of dollars.

Inventory turnover $=$ Cost of sales (DATA41, COGS) / Inventory (DATA3, INVT), not calculated for firms without inventory.

Accounts receivable turnover $=$ Sales $($ DATA12, SALE) $/$ Accounts receivable $($ DATA2, RECT).

Accounts payable turnover $=$ Cost of sales $($ DATA41, COGS) $/$ Accounts payable (DATA70, AP).

Median Industry-adjusted variables = the unadjusted variable (defined above) less the median calculated by year, across all firms in the Compustat database in the list firm's four-digit SIC code.

${ }^{*}$ Mean (or median) is significantly different than zero in the predicted direction at $\mathrm{p}=0.05$ or better using a one-tailed student t-test (Wilcoxon signed-rank test). 
TABLE 3

\section{List firms compared to industry benchmarks for risk measures, 1994-2008}

\section{Balance sheet measures}

Current ratio

Debt to assets

Altman Z-score

Variability of performance

Std. dev. of sales

Std. dev. of net income

Std. dev. of cash from operations

\begin{tabular}{c} 
List firms \\
unadjusted variables \\
\hline
\end{tabular}

N Mean Median

2,972

2.101

3,746

0.154

2,789

6.457

1.573

0.123

4.094

3,748

0.032

3,425

0.026

3,748
List firms

median industry-adjusted variables

\begin{tabular}{crr}
\hline $\mathbf{N}$ & Mean & Median \\
& & \\
2,972 & 0.059 & $-0.132 *$ \\
3,746 & $0.044^{*}$ & $.009 *$ \\
2,789 & $3.065 *$ & $0.719 *$ \\
& & \\
3,748 & -0.003 & $-0.006^{*}$ \\
3,425 & $-0.005^{*}$ & $-0.007^{*}$ \\
3,748 & $-0.004^{*}$ & $-0.004^{*}$
\end{tabular}

\section{Notes to Table 3:}

This table reports means and medians for the period 1994-2008 for the 742 list firms (100 firms on the Business Ethics list for each of eight years with some firm-year observations leaving the sample due to missing data).

All data are retrieved from Compustat to compute the following variables:

Current ratio $=$ Total current assets (DATA4, ACT) $/$ Total current liabilities (DATA5, LCT).

Debt to assets $=$ Total long-term debt (DATA9, DLTT) $/$ Total assets (DATA6, AT).

Altman Z-score $=(1.2 \times \mathrm{X} 1)+(1.4 \times \mathrm{X} 2)+(3.3 \times \mathrm{X} 3)+(0.6 \times \mathrm{X} 4)+(0.999 \times \mathrm{X} 5)$.

$\mathrm{X} 1=[$ Total current assets (DATA4, ACT) - Total current liabilities (DATA5, LCT) $/$ Total assets

(DATA6, AT).

X2 = Retained earnings (DATA36, RE)/ Total assets (DATA6, AT).

X3 = EarningsB4inttax / Total assets (DATA6), with EarningsB4inttax $=$ Net Income $($ DATA172) + Interest expense (DATA15, XINT ) + Tax Expense (DATA16, TXT).

X4 = [Price per share (DATA199, PRCC_F) $\times$ Shares outstanding (DATA25, CSHO)] / Total liabilities (DATA181, LT).

X5 = Sales (DATA12, SALE) / Total assets (DATA6, AT).

Std. dev. of sales = Standard deviation of the prior eight quarters' [Sales (Quarterly_DATA2, SALEQ) / Total assets (Quarterly_DATA44, ATQ)].

Std. dev. of net income = Standard deviation of the prior eight quarters' [Income before ext. (Quarterly_DATA8, IBQ) / Total assets (Quarterly_DATA44, ATQ)].

Std. dev. of cash from operations = Standard deviation of the prior eight quarters' Net operating cash flow

(Quarterly_DATA108, OANCFY, adjusted to reflect quarterly data) / Total assets (Quarterly_DATA44, ATQ).

Median Industry-adjusted variables = the unadjusted variable (defined above) less the median calculated by year, across all firms in the Compustat database in the list firm's four-digit SIC code.

${ }^{*}$ Mean (or median) is significantly different than zero in the predicted direction at $\mathrm{p}=0.05$ or better using a one-tailed student t-test (median test). 
TABLE 4

List firms compared to industry benchmarks one and two years after inclusion on Business Ethics list

\section{Panel A: Financial performance measures}

\section{Profitability variables}

Sales to total assets

Cost of sales margin

Return on assets

Return on equity

\section{Growth variables}

Sales growth

Cost of sales margin growth

Net income growth

Efficiency variables

Inventory turnover

Acc. receivable turnover

Acc. payable turnover

\author{
One year after appearing on \\ Business Ethics list

\begin{tabular}{lcc}
\multicolumn{3}{c}{$\begin{array}{c}\text { Median industry-adjusted } \\
\text { variables }\end{array}$} \\
\hline N & Mean & Median
\end{tabular}

601
737
737
737

737

737

737

0.146*

$-0.114^{*}$

$0.173 *$

$-0.240$
0.093*
$-0.067 *$
$0.056 *$
$0.085 *$

$0.036^{*}$

$0.001^{*}$

0.011

$-0.910$

0.000

$0.060^{*}$

632

$47.562 *$

715

$2.249 *$

$0.619 *$

$0.072 *$

$1.576^{*}$
Two years after appearing on Business Ethics list

\begin{tabular}{ccr}
\multicolumn{3}{c}{$\begin{array}{c}\text { Median industry-adjusted } \\
\text { variables }\end{array}$} \\
\hline $\mathbf{N}$ & Mean & \multicolumn{1}{c}{ Median } \\
& & \\
606 & $0.171^{*}$ & $0.063^{*}$ \\
731 & -0.038 & $-0.056^{*}$ \\
731 & $0.155^{*}$ & $0.039^{*}$ \\
731 & -0.439 & $0.060^{*}$ \\
& & \\
663 & $0.069^{*}$ & 0.000 \\
663 & $0.014^{*}$ & $0.001^{*}$ \\
685 & 1.579 & $0.046^{*}$ \\
& & \\
630 & $57.055^{*}$ & $0.449^{*}$ \\
714 & $2.314^{*}$ & $0.118^{*}$ \\
722 & $2.959^{*}$ & $0.013^{*}$
\end{tabular}

Notes to Table 4:

This table reports median industry-adjusted variables for the 742 list firms (100 firms on the Business Ethics list for each of eight years with some firm-year observations leaving the sample due to missing data) one year and two years after appearing on the list.

Median industry-adjusted variables are the unadjusted variable (defined below) less the median calculated by year, across all firms in the Compustat database in the list firm's four-digit SIC code.

All data are retrieved from Compustat to compute the following variables:

Sales to total assets $=$ Sales (DATA12, SALE) $/$ Total assets (DATA6, TA), not calculated for banks.

Cost of sales margin = Cost of sales (DATA41, COGS) $/$ Sales (DATA12, SALE), not calculated for banks.

Return on assets $=$ Net income $($ DATA172, NI) $/$ Total assets (DATA6, TA).

Return on equity $=$ Net income $(172, \mathrm{NI}) /$ Common equity (DATA11, CEQT).

Sales growth $=\left(\right.$ Sales $_{t}-$ Sales $\left._{t-1}\right) /$ Sales $_{t-1}$

Cost of sales margin growth $=\left(\right.$ Cost of sales margin ${ }_{t}-$ Cost of sales margin $\left._{t-1}\right) /$ Cost of sales margin ${ }_{t-1}$.

Net income growth $=\left(\right.$ Net income $_{t}-$ Net income $\left._{t-1}\right) /$ Net income $_{t-1}$, where Net income $=$ DATA172 (NI) in millions of dollars.

Inventory turnover $=$ Cost of sales $($ DATA41, COGS) $/$ Inventory $($ DATA3, INVT), not calculated for firms without inventory.

Accounts receivable turnover $=$ Sales (DATA12, SALE) $/$ Accounts receivable (DATA2, RECT).

Accounts payable turnover $=$ Cost of sales $($ DATA41, COGS) $/$ Accounts payable $($ DATA70, AP).

* Mean (or median) is significantly different than zero in the predicted direction at $\mathrm{p}=0.05$ or better using a one-tailed student t-test (median test). 
TABLE 4 (continued)

List firms compared to industry benchmarks one and two years after inclusion on Business Ethics list

\section{Panel B: Risk measures}

\section{Balance sheet measures}

Current ratio

Debt to assets

Altman Z-score

\section{Variability of performance}

Std. dev. of sales

Std. dev. of net income

Std. dev. of cash from

operation

\author{
One year after appearing \\ on Business Ethics list \\ Median industry-adjusted \\ variables
}

N Mean Median

599

737

0.007

$0.027 *$

$-0.104 *$

$0.008 *$

562

$3.447 *$

$1.448 *$

737

737

$-0.006^{*}$

$-0.007 *$

$-0.008 *$

690
$-0.011^{*}$

-0.010 *
$-0.006^{*}$
Two years after appearing on Business Ethics list

\section{Median industry-adjusted} variables

\begin{tabular}{ccc}
\hline $\mathbf{N}$ & Mean & Median \\
& & \\
600 & $0.163^{*}$ & -0.071 \\
731 & $0.034^{*}$ & $0.010^{*}$ \\
571 & $2.623^{*}$ & $1.122^{*}$
\end{tabular}

$$
727
$$

0.002

$-0.006^{*}$

727

$-0.004$

$-0.005^{*}$

$675-0.007 *$

$-0.007^{*}$

Notes to Table 4:

This table reports median industry-adjusted variables for the 742 list firms (100 firms on the Business Ethics list for each of eight years with some firm-year observations leaving the sample due to missing data) one year and two years after appearing on the list.

Median industry-adjusted variables are the unadjusted variable (defined below) less the median calculated by year, across all firms in the Compustat database in the list firm's four-digit SIC code.

All data are retrieved from Compustat to compute the following variables:

Current ratio $=$ Total current assets $($ DATA4, ACT) $/$ Total current liabilities (DATA5, LCT).

Debt to assets $=$ Total long-term debt (DATA9, DLTT) $/$ Total assets $($ DATA6, AT).

Altman Z-score $=(1.2 \times \mathrm{X} 1)+(1.4 \times \mathrm{X} 2)+(3.3 \times \mathrm{X} 3)+(0.6 \times \mathrm{X} 4)+(0.999 \times \mathrm{X} 5)$.

$\mathrm{X} 1=[$ Total current assets (DATA4, ACT) - Total current liabilities (DATA5, LCT) $]$ Total assets (DATA6, AT).

X2 = Retained earnings (DATA36, RE)/ Total assets (DATA6, AT).

X3 = EarningsB4inttax / Total assets (DATA6), with EarningsB4inttax = Net Income (DATA172) + Interest expense (DATA15, XINT) + Tax Expense (DATA16, TXT).

X4 = [Price per share $($ DATA199, PRCC_F $) \times$ Shares outstanding (DATA25, CSHO) $] /$ Total liabilities (DATA181, LT). X5 = Sales (DATA12, SALE) / Total assets (DATA6, AT).

Std. dev. of sales $=$ Standard deviation of the prior eight quarters' [Sales (Quarterly_DATA2, SALEQ) / Total assets (Quarterly_DATA44, ATQ)].

Std. dev. of net income = Standard deviation of the prior eight quarters' [Income before ext. (Quarterly_DATA8, IBQ) / Total assets (Quarterly_DATA44, ATQ)].

Std. dev. of cash from operations = Standard deviation of the prior eight quarters' Net operating cash flow (Quarterly_DATA108, OANCFY, adjusted to reflect quarterly data) / Total assets (Quarterly_DATA44, ATQ).

${ }^{*}$ Mean (or median) is significantly different than zero in the predicted direction at $\mathrm{p}=0.05$ or better using a one-tailed student t-test (median test). 
TABLE 5

Ordinary least-squares regressions of market value of equity models

\begin{tabular}{|c|c|c|c|c|c|}
\hline & \multirow[b]{2}{*}{$\begin{array}{l}\text { Pred } \\
\text { Sign }\end{array}$} & \multicolumn{2}{|c|}{$\begin{array}{c}\text { Complete time-series } \\
\begin{array}{c}1994 \text { to } 2008 \\
\mathrm{~N}=101,995^{\mathrm{a}} \\
\end{array} \\
\end{array}$} & \multicolumn{2}{|c|}{$\begin{array}{c}\text { List years only } \\
1998 \text { to } 2005 \\
N=55,459^{b} \\
\end{array}$} \\
\hline & & $\begin{array}{c}\text { Parameter } \\
\text { estimate }\end{array}$ & $\begin{array}{c}\text { student } \\
\text { t-statistic }\end{array}$ & $\begin{array}{c}\text { Parameter } \\
\text { estimate }\end{array}$ & $\begin{array}{c}\text { student } \\
\text { t-statistic }\end{array}$ \\
\hline Intercept & & -412.676 & $-20.88 *$ & -54.045 & $-2.25 *$ \\
\hline$B V E$ & + & 1.856 & $514.27 *$ & 2.108 & $340.51^{*}$ \\
\hline ETHICAL_EVER & + & $2,134.324$ & $80.87 *$ & $1,983.770$ & $45.71 *$ \\
\hline ETHICAL_IN_YR & + & $3,152.818$ & $51.19 *$ & $2,480.809$ & $35.41^{*}$ \\
\hline$A B \_E A R N$ & + & 2.060 & $113.03 *$ & 1.957 & $68.40 *$ \\
\hline$R \& D$ & + & 20.216 & $2.42 *$ & 37.198 & $3.27 *$ \\
\hline MKT_SHARE & + & 497.541 & $14.13^{*}$ & 109.015 & $2.01^{*}$ \\
\hline Year & $+/-$ & Suppressed & & Suppressed & \\
\hline Industry & $+/-$ & Suppressed & & Suppressed & \\
\hline Adj-R ${ }^{2}$ & & $84.88 \%$ & & $80.24 \%$ & \\
\hline
\end{tabular}

Notes to Table 5:

a This regression includes time-series observations from 1994 through 2008 for all firms in Compustat. Data have been adjusted for outliers; observations with studentized residuals greater than or equal to the absolute value of three have been given a weight of zero in the regression.

b This regression includes time-series observations for all firms in Compustat for the list years only, 1998 - 2005 (list firms are evaluated on historical data; this time-series corresponds to list years 2000-2007). Data have been adjusted for outliers; observations with studentized residuals greater than or equal to the absolute value of three have been given a weight of zero in the regression.

All data are retrieved from Compustat to compute the following variables (measured at fiscal year end): $\boldsymbol{M V E}=$ market value of equity = Price per share (DATA199, PRCC_F) $\times$ Shares outstanding (DATA25, CSHO), in millions of dollars.

$\boldsymbol{B V E}=$ book value of equity = total assets (DATA6, AT) less total liabilities (DATA181, LT), in millions of dollars. We chose to use book value of equity because using total assets and total liabilities resulted in high variance inflation factors.

ETHICAL_EVER = indicator variable = 1 if firm is on the Business Ethics List in any year from 2000 to 2007, 0 otherwise.

ETHICAL_IN_YR = indicator variable $=1$ if firm is on the Business Ethics List for that year, 0 otherwise.

$\boldsymbol{A B} \_\boldsymbol{E A R N}=$ abnormal earnings $=$ Net income $(\mathrm{DATA} 172, \mathrm{NI})-[0.10 \times$ prior year's equity $($ DATA11, CEQT), in millions of dollars.

$\boldsymbol{R} \boldsymbol{\&} \boldsymbol{D}=\mathrm{R} \& \mathrm{D}$ expense (DATA46, XRD) / Total sales (DATA12, SALE), in millions of dollars.

MKT_SHARE $=$ market share $=$ Total sales $\left(\right.$ DATA12, SALE) $/ \sum$ Total sales (DATA12, SALE) for all firms in four-digit SIC code, in percent.

Year $=$ year indicator variable $=1$ if observation is from that year, and 0 otherwise.

Industry $=$ industry indicator variable $=1$ if firm is in two-digit SIC code, and 0 otherwise.

${ }^{*}$ Co-efficient is significantly different than zero at $\mathrm{p}=0.05$ or better using a two-tailed student t-test. 


\section{TABLE 6 \\ Ordinary least-squares regressions of market value of equity models scaled by lagged market value of equity}

$$
\text { MVE Model: } \quad \begin{aligned}
M V E_{i, t}= & B V E \_L a g M V E_{i, t}+E T H I C A L \_L a g M V E_{i}+E T H I C A L \_I N \_Y R \_L a g M V E_{i, t} \\
& +A B \_E A R N \_L a g M V E_{i, t}+R \& D \_L a g M V E_{i, t}+M K T \_S H A R E \_L a g M V E_{i, t} \\
& +L_{a g M V E_{i, t}}+\text { Year }_{t}+\text { Industry }_{j}+\varepsilon_{i, t},
\end{aligned}
$$

\begin{tabular}{|c|c|c|c|c|c|}
\hline & \multirow[b]{2}{*}{$\begin{array}{l}\text { Pred } \\
\text { Sign }\end{array}$} & \multicolumn{2}{|c|}{$\begin{array}{c}\text { Complete time-series } \\
1994 \text { to } 2008 \\
\mathrm{~N}=102,097^{\mathrm{a}} \\
\end{array}$} & \multicolumn{2}{|c|}{$\begin{array}{c}\text { List years only } \\
1998 \text { to } 2005 \\
N=55,493^{b} \\
\end{array}$} \\
\hline & & $\begin{array}{c}\text { Parameter } \\
\text { estimate }\end{array}$ & $\begin{array}{c}\text { student } \\
\text { t-statistic }\end{array}$ & $\begin{array}{c}\text { Parameter } \\
\text { estimate }\end{array}$ & $\begin{array}{r}\text { student } \\
\text { t-statistic }\end{array}$ \\
\hline Intercept & & -571.860 & -53.83* & 114.720 & 9.65* \\
\hline BVE_LagMVE & + & 0.121 & 1.01 & 0.166 & $1.02^{*}$ \\
\hline ETHICAL_EVER_LagMVE & + & 1751.935 & .840 & $2,150.794$ & 0.65 \\
\hline ETHICAL_IN_YR_LagMVE & + & $15,087.000$ & $1.87 \dagger$ & $15,244.000$ & $1.78 \dagger$ \\
\hline$A B \_E A R N \_L \overline{a g} M \bar{V} E$ & + & -0.229 & $-2.49 *$ & -0.529 & $-3.71 *$ \\
\hline$R \& D \_L a g M V E$ & + & 0.533 & 0.12 & -0.173 & -0.04 \\
\hline$M K T \_S H A R E \_L a g M V E$ & + & -257.176 & -0.83 & -336.744 & -0.79 \\
\hline $\operatorname{Lag} \bar{M} V E$ & + & 0.967 & 1691.38* & 0.980 & $1504.76^{*}$ \\
\hline Year & $+/-$ & Suppressed & & Suppressed & \\
\hline Industry & $+/-$ & Suppressed & & Suppressed & \\
\hline Adj-R ${ }^{2}$ & & $96.66 \%$ & & $97.66 \%$ & \\
\hline
\end{tabular}

Notes to Table 6:

a This regression includes time-series observations from 1994 through 2008 for all firms in Compustat. Data have been adjusted for outliers; observations with studentized residuals greater than or equal to the absolute value of three have been given a weight of zero in the regression.

b This regression includes time-series observations for all firms in Compustat for the list years only, 1998 - 2005 (list firms are evaluated on historical data; this time-series corresponds to list years 2000-2007). Data have been adjusted for outliers; observations with studentized residuals greater than or equal to the absolute value of three have been given a weight of zero in the regression.

All data are retrieved from Compustat to compute the following variables (measured at fiscal year end): $\boldsymbol{M V E}=$ market value of equity $=$ Price per share $($ DATA199, PRCC_F $) \times$ Shares outstanding $($ DATA25, CSHO), in millions of dollars.

$\boldsymbol{B V E} \_$LagMVE = Book value of equity, as defined in prior table, scaled by prior year's market value of equity. We chose to use book value of equity because using total assets and total liabilities resulted in high variance inflation factors.

ETHICAL_EVER_LagMVE = indicator variable for firm being on the Business Ethics List in any year from 2000 to 2007, scaled by prior year's market value of equity.

ETHICAL_IN_YR_LagMVE = indicator variable for firm being on the Business Ethics List for that year, scaled by prior year's market value of equity.

AB_EARN_LagMVE = abnormal earnings, as defined in prior table, scaled by prior year's market value of equity.

$\boldsymbol{R} \& D \_$LagMVE = R\&D expense (DATA46, XRD), scaled by prior year's market value of equity

MKT_SHARE_LagMVE = market share, as defined in prior table, scaled by prior year's market value of equity.

LagMVE = prior year's market value of equity.

Year $=$ year indicator variable $=1$ if observation is from that year, and 0 otherwise.

Industry = industry indicator variable $=1$ if firm is in two-digit SIC code, and 0 otherwise.

* Co-efficient is significantly different than zero at $\mathrm{p}=0.05$ or better using a two-tailed student t-test.

†Co-efficient is significantly different from zero at $\mathrm{p}=0.10$ or better using a two-tailed student t-test. 